\title{
Penggunaan Video untuk Memperkaya Share Informasi Pembelajaran Fisika pada Model Two Stay Two Stray
}

\section{The Use of Video to Enhance Shared Information of Physics Teaching using Two Stay Two Stray Model}

\author{
Munawaroh, Upik Yelianti, Damris M* \\ Program Studi Magister Pendidikan IPA Universitas Jambi \\ * coresponding author: damrism@gmail.com
}

\begin{abstract}
Model of teaching Two Stay Two Stray (TSTS) requires group of students to share information back to their own group from their counterpart groups. The shared information is limited as oral information dominantly shared during the teaching processes. The objective of this study was to improve shared information between groups of students in physics learning by using video at Madrasah Aliyah Nurul Jalal Tebo. The video was played to enhance shared information between groups of students using TSTSlearning model. Video was shown to the incoming students to enhance oral explanation. The number of information shared between these groups of students was compared with conventional TSTS class. Two-way anova was used to analyze the data. The results show that the use of video in TSTS learning is not significantly affect the shared information between groups of students.
\end{abstract}

Keyword: Learning outcomes, motivation to learn, two stay two stray, video enrichment

\begin{abstract}
Abstrak
Model pengajaran Two Stay Two Stray (TSTS) mengharuskan sekelompok siswa untuk berbagi informasi kembali ke kelompok mereka sendiri dari kelompok siswa yang lain. Selama proses pengajaran, biasanya informasi yang dibagikan terbatas karena informasi yang diberikan lebih banyak disampaikan secara lisan. Tujuan penelitian ini adalah untuk meningkatkan informasi yang dibagikan antar kelompok siswa Madrasah Aliyah Nurul Jalal Tebo dalam pembelajaran fisika dengan menggunakan video. Video diputar untuk meningkatkan informasi yang tersampaikan antar kelompok siswa dengan menggunakan model pembelajaran TSTS. Video diperlihatkan kepada siswa yang menghadang untuk membantu penjelasan yang dilakukan secara lisan. Jumlah informasi yang dibagikan antara kelompok siswa dibandingkan dengan kelas TSTS konvensional. Anova dua arah digunakan untuk menganalisis data. Hasil penelitian menunjukkan bahwa penggunaan video dalam pembelajaran TSTS secara signifikan mempengaruhi shared informasi antar kelompok dan prestasi belajar siswa.
\end{abstract}

Kata Kunci: Hasil belajar, motivasi, pengayaan video, two stay two stray 


\section{PENDAHULUAN}

Sumber daya manusia yang berkualitas dalam kehidupan bangsa ditentukan oleh faktor pendidikan. Hal ini sesuai dengan tujuan pendidikan nasional, yaitu sebagai salah satu sektor pembangunan nasional dalam upaya mencerdaskan kehidupan bangsa, mempunyai visi terwujudnya sistem pendidikan yang kuat yang berguna untuk mempersiapkan manusia Indonesia agar menjadi warga negara yang berkualitas, beriman, kreatif, inovatif, produktif, dan afektif serta mampu berkontribusi pada kehidupan bermasyarakat, berbangsa, bernegara, sehingga mampu menjawab tantangan zaman yang selalu berubah.

Upaya peningkatan kualitas pendidikan sangat perlu dilakukan oleh setiap elemen pendidikan, dari pemerintah pusat hingga pemerintah daerah agar tujuan pendidikan tercapai. Banyak usaha yang dilakukan oleh pemerintah dalam meningkatkan mutu pendidikan, diantaranya adalah melakukan pengembangan dan penyempurnaan kurikulum, melengkapi sarana dan prasarana, meningkatkan kompetensi guru melalui penataran, pelatihan dan seminar untuk guru fisika serta menyediakan buku pelajaran di sekolah. Berbagai usaha yang dilakukan pemerintah bertujuan untuk meningkatkan kualitas hasil belajar dan proses belajar mengajar. Dalam upaya mewujudkan situasi dan kondisi belajar yang optimal.

Kegiatan pembelajaran di dalam kelas tidak dapat dilepaskan dari strategi, teknik, media dan model pembelajaran. Strategi, teknik, media dan model pembelajaran merupakan suatu tindakan tertentu yang harus dilakukan guru dan siswa dalam pembelajaran agar tujuan pembelajaran dapat tercapai. Dalam menciptakan kegiatan belajar mengajar yang menarik, guru harus mampu memilih metode atau model pembelajaran yang tepat. Penggunaan metode atau model pembelajaran yang menarik dan melibatkan siswa dalam kegiatan belajar mengajar memungkinkan siswa menjadi lebih cepat menerima, memahami dan mencerna informasi atau materi-materi yang disampaikan.

Terdapat beberapa model pembelajaran yang dapat digunakan dalam kegiatan pembelajaran. Model-model tersebut antara lain model pembelajaran langsung (direct instruction) atau dikenal dengan active teaching, model pembelajaran kooperatif (cooperative learning), model pembelajaran berbasis masalah (problem based learning), yang mampu melibatkan siswa dalam kegiatan pembelajaran (Suprijono, 2009). Model pembelajaran yang dapat dipilih oleh seorang guru untuk mencapai kegiatan pembelajaran yang menyenangkan adalah model pembelajaran yang melibatkan siswa aktif dalam belajar baik secara mental, fisik maupun sosial. Salah satunya dengan menerapkan model pembelajaran kooperatif.

Salah satu model pembelajaran kooperatif yaitu TSTS. Lie (2002) menyatakan bahwa model pembelajaran kooperatif TSTS merupakan model pembelajaran dengan kelompok siswa dimana ada anggota kelompok yang tinggal dan bertamu ke kelompok lain untuk mendapatkan informasi pembelajaran.

Informasi yang di share pada kelompok tamu biasanya diberikan secara lisan. Sehingga informasi yang dishare ke grup asal biasanya sudah tidak utuh lagi. Kelemahan TSTS in diatasi dengan pemutaran video berisi materi ajar selama kunjungan kelompok. Diharapkan dengan penggunaan video dapat meningkatkan shared informasi ke kelompok asal dan prestasi belajar siswa. Siswa dengan kemampuan akademik yang baik agar siswa mampu menjelaskan kembali kepada anggota kelompoknya. 
Video pembelajaran diharapkan dapat memperkaya shared informasi dan prestasi belajar siswa. Video dapat mempermudah anggota kelompok yang bertamu menjelaskan kembali pada kelompok asal. Dengan adanya penjelasan dan video pembelajaran yang diamati langsung oleh anggota kelompok yang tinggal maka kelompok yang tinggal tersebut akan mudah memahami materi-materi dari kelompok lain dan berkemungkinan dapat meningkatkan hasil belajar siswa.

Berdasarkan observasi yang telah dilakukan di Madrasah Aliyah Nurul Jalal Kabupaten Tebo, pembelajaran fisika biasanya berlangsung dengan menggunakan model konvensional dan model TSTS tanpa disertai dengan video pembelajaran. Terdapat beberapa masalah yang dihadapi, diantaranya banyak siswa yang belum memahami materi pelajaran fisika pada materi perpindahan kalor serta hasil belajar siswa masih banyak yang belum mencapai KKM (Kriteria Ketuntasan Minimal). KKM di Madrasah Aliyah Nurul Jalal Kabupaten Tebo adalah 75 .

Pembelajaran menggunakan model TSTS tanpa disertai video juga terdapat masalah yang disebabkan karena informasiinformasi materi yang diterima angggota kelompok yang bertamu berupa penjelasan-penjelasan lisan, serta bahan bacaan yang berkaitan dengan materi belum menunjukkan hasil yang maksimal. Hal ini menyebabkan siswa mengalami kesulitan dalam menjelaskan kembali informasi materi-materi yang didapat kepada anggota kelompok asalnya. Selain itu, siswa juga kurang aktif dalam mengajukan pertanyaan dalam proses pembelajaran. Akibatnya, siswa cenderung untuk cepat melupakan materi-materi yang telah diajarkan, serta kurang berlatih untuk mengerjakan soal.

Untuk mengatasi berbagai permasalahan tersebut, upaya yang perlu dilakukan oleh guru diantaranya menciptakan suasana belajar yang lebih baik lagi. Salah satunya dengan menggunakan model pembelanjaran yang menarik yang dapat meningkatkan minat dan motivasi siswa untuk belajar sehingga diharapkan dapat menciptakan pembelajaran yang aktif dan hasil belajar siswa pun akan meningkat.

Alternatif untuk dapat mengatasi permasalahan dapat dilakukan dengan menggunakan model pembelajaran kooperatif tipe TSTS yang diperkaya dengan video dimana nantinya guru tidak lagi merupakan satu-satunya penyaji informasi tetapi sebaliknya sebagai fasilitator yang berperan aktif dalam mempersiapkan fasilitas pembelajaran. Model pembelajaran tersebut akan lebih efektif bila didukung dengan motivasi belajar siswa yang baik. Menurut Widiasworo (2015) motivasi merupakan energi penggerak dan pengarah, yang dapat memperkuat dan mendorong seseorang untuk bertingkah laku.

Prasatya dkk. (2017) dengan menggunakan model pembelajaran TSTS berbasis masalah pada pembelajaran IPA siswa kelas V SD. Hasilnya menunjukkan bahwa kelompok siswa yang mengikuti pembelajaran menggunakan model pembelajaran menunjukkan hasil belajar IPA lebih tinggi dibandingkan dengan kelompok siswa yang tidak dibelajarkan menggunakan model pembelajaran TSTS.

Mengingat begitu pentingnya pelajaran fisika di sekolah, maka diperlukan suatu model pembelajaran yang tepat dalam pembelajaran agar tujuan yang diharapkan dapat tercapai sesuai dengan yang diinginkan. Salah satu bentuk modelnya yaitu dengan menggunakan model pembelajaran kooperatif tipe TSTS untuk itu dilakukan penelitian mengenai pengaruh model pembelajaran kooperatif TSTS yang diperkaya dengan video dan motivasi terhadap hasil belajar fisika siswa. 


\section{METODE PENELITIAN}

Penelitian ini dilaksanakan di Madrasah Aliyah Nurul Jalal Kabupaten Tebo Provinsi Jambi. Subjek penelitiannya adalah siswa-siswi kelas $\mathrm{X}$ (Sepuluh). Penelitian ini dilaksanakan pada semester genap tahun ajaran 2018/2019 pada bulan Mei 2019.

Penelitian ini merupakan penelitian kuantitatif, dengan jenis metode penelitian yang digunakan dalam penelitian ini adalah metode eksperimen semu menggunakan dengan desain faktorial $3 \times 2$ (Tabel 1).

Tabel 1. Rancangan Faktorial (3x2)

\begin{tabular}{cccc} 
Model & $\begin{array}{c}\text { Model } \\
\text { TSTS } \\
\text { video } \\
\left(\mathrm{A}_{1}\right)\end{array}$ & $\begin{array}{c}\text { Model Two } \\
\text { Stay Two } \\
\text { Stray } \\
\left(\mathrm{A}_{2}\right)\end{array}$ & $\begin{array}{c}\text { Model } \\
\text { Konven } \\
\text { sional } \\
\left(\mathrm{A}_{3}\right)\end{array}$ \\
\hline Motivasi & $\mathrm{A}_{1} \mathrm{~B}_{1}$ & $\mathrm{~A}_{2} \mathrm{~B}_{1}$ & $\mathrm{~A}_{3} \mathrm{~B}_{1}$ \\
\hline Tinggi $\left(\mathrm{B}_{1}\right)$ & $\mathrm{A}_{1} \mathrm{~B}_{2}$ & $\mathrm{~A}_{2} \mathrm{~B}_{2}$ & $\mathrm{~A}_{3} \mathrm{~B}_{2}$
\end{tabular}

Populasi dalam penelitian ini adalah seluruh siswa-siswi kelas X di Madrasah Aliyah Nurul Jalal Kabupaten Tebo Provinsi Jambi tahun ajaran 2018/2019. Sedangkan sampel dalam penelitian ini terdiri dari tiga kelas yaitu kelas Kelas X A sebagai kelas eksperimen satu, kelas X B sebagai kelas eksperimen dua, dan kelas $\mathrm{X}$ D sebagai kelas kontrol. Jumlah siswa pada masing-masing kelas tersebut sebanyak 24 orang siswa

Instrumen yang digunakan dalam pengumpulan data adalah angket motivasi siswa, dan tes hasil belajar. Angket motivasi siswa diberikan di awal pembelajaran dan soal tes hasil belajar diberikan setelah perlakuan.

Soal tes yang dibuat terlebih dahulu dilakukan uji coba untuk mengetahui kelayakannya sebagai instrumen penelitian. Uji instrumen yang dilakukan meliputi uji validitas, uji reliabilitas, uji taraf kesukaran, dan uji daya beda.

Setelah ketiga kelas tersebut diberikan perlakuan, pada akhir pertemuan diberikan soal posttest berupa soal pilihan ganda. Setelah semua data penelitian didapat, kemudian peneliti mengolah data dengan uji hipotesis menggunakan Anova dengan bantuan SPSS 16.0. Sebelum dilaksanakan uji hipotesis terlebih dahulu dilakukan uji normalitas dan uji homogenitas data.

Data yang diuji normalitas dan homogenitas adalah angket motivasi belajar siswa, diperoleh hasil pada kelas eksperimen satu yaitu 0,173>0,05, sedangkan pada kelas eksperimen dua yaitu $0,130>0,05$ serta kelas kontrol 0,070>0,05. Dapat disimpulkan bahwa ketiga kelas berdistribusi normal. Dengan taraf kepercayaan $95 \%$ atau nilai signifikansi > 0,05. Kemudian dilakukan uji homogenitas diperoleh nilai signifikansi $0,328>0,05$, sehingga dapat disimpulkan bahwa data angket motivasi belajar siswa berdistribusi homogen.

Uji normalitas pada kelas eksperimen satu yaitu $0,115>0,05$, pada kelas eksperimen dua yaitu $0,113>0,05$, dan pada kelas kontrol 0,118>0,05. Dapat disimpulkan bahwa nilai posttest berdistribusi normal. Uji homogenitas diperoleh nilai sig. $0,206 \geq 0,05$ yang berarti tidak ada perbedaan varian dari beberapa kelompok (data homogen).

Setelah data berdistribusi normal dan homogen selanjutnya data hasil penelitian dianalisis menggunakan uji Anova. Uji Anova bertujuan untuk membandingkan lebih dari dua rata-rata.

\section{HASIL DAN PEMBAHASAN}

Pada kelas eksperimen satu terdapat 14 siswa yang memiliki motivasi tinggi dan 10 siswa yang memiliki motivasi rendah. Pada kelas eksperimen dua terdapat 10 
siswa yang memiliki motivasi tinggi dan 14 siswa yang memiliki motivasi rendah. Sedangkan pada kelas kontrol terdapat 11 siswa yang memiliki motivasi tinggi dan 13 siswa yang memiliki motivasi rendah.

Dari hasil uji Anova diperoleh bahwa nilai signifikansi untuk motivasi belajar siswa $0,00<0,05$. Dimana nilai signifikansi motivasi belajar siswa lebih kecil dari pada 0,05 sehingga dapat disimpulkan bahwa rata-rata motivasi belajar siswa pada ketiga kelas berbeda. Dari hasil signifikansi dapat disimpulkan bahwa $\mathrm{H}_{0}$ ditolak, jika $\mathrm{H}_{0}$ maka $\mathrm{H}_{\mathrm{a}}$ diterima artinya terdapat pengaruh motivasi belajar siswa terhadap hasil belajar siswa.

Motivasi belajar berpengaruh terhadap hasil belajar disebabkan karena motivasi merupakan suatu dorongan yang timbul oleh adanya rangsangan dari dalam maupun dari luar sehingga seseorang berkeinginan untuk mengadakan perubahan tingkah laku/aktivitas tertentu sehingga lebih baik dari keadaan sebelumnya. Jika dalam diri seseorang terdapat motivasi yang baik untuk belajar maka hasil belajar akan baik pula. Dengan kata lain, adanya usaha yang tekun dan didasari oleh motivasi yang kuat, maka seseorang yang belajar akan dapat melahirkan prestasi yang baik. Intensitas motivasi seorang siswa akan sangat menentukan tingkat pencapaian prestasi belajarnya (Sardiman, 2014).

Juniari dkk. (2014) meneliti mengenai pengaruh model pembelajaran POE dan motivasi belajar terhadap hasil belajar IPA siswa kelas V SD menyimpulkan bahwa model pembelajaran POE (PredictObserve-Explain) dan motivasi belajar memberikan pengaruh yang baik terhadap hasil belajar IPA. Sejalan dengan hal tersebut, Daud (2012) meneliti mengenai pengaruh kecerdasan emosional (EQ) dan motivasi belajar terhadap hasil belajar biologi siswa SMA 3 Negeri Kota Palopo; motivasi belajar berpengaruh positif dan signifikan terhadap hasil belajar biologi.

Hasil analisis data secara umum menunjukkan bahwa hasil belajar kelas eksperimen 1 (model TSTS+video) dan kelas eksperimen 2 (model TSTS) lebih tinggi dari kelas kontrol. Tetapi hasil belajar antara kedua kelas eksperimen tersebut tidak menunjukkan adanya perbedaan yang signifikan.

Uji signifikansi kelas eksperimen 1 (TSTS + video) dengan kelas kontrol (model konvensional) diperoleh nilai Tukey 0,000 $(<0,05)$. Hasil uji pada kelas eksperimen 2 (TSTS tanpa video) dengan kelas kontrol diperoleh nilai Tukey 0,02 $(<0,05)$. Uji Tukey kelas eksperimen 1 dengan kelas eksperimen 1 diperoleh nilai uji 0,090 $(>0,05)$.

Pembelajaran dengan model TSTS merupakan pembelajaran dengan sistem berkelompok yang bertujuan agar siswa dapat saling belajar dan bekerja sama, saling membantu memecahkan masalah, dan saling mendorong satu sama lain untuk berprestasi, dan bertanggung jawab. Model ini juga melatih siswa untuk bersosialisasi dengan baik. Muhaji dkk. (2017) meneliti pengaruh penerapan model pembelajaran kooperatif tipe TSTS dan motivasi belajar terhadap hasil belajar siswa mata pelajaran IPS siswa SMPN 1 Kecamatan Ngebel Kabupaten Ponorogo. Pembelajaran menggunakan model TSTS berpengaruh terhadap hasil belajar IPS.

Rahayu dkk. (2014) menambahkan bahwa model pembelajaran kooperatif tipe TSTS berbantuan media power point berpengaruh terhadap hasil belajar PKn siswa kelas V SD Gugus II Kecamatan Kuta Badung tahun pelajaran 2013/2014.

Berdasarkan wawancara siswa serta pengalaman langsung di Madrasah Aliyah Nurul Jalal Kabupaten Tebo saat melaksanakan kegiatan belajar mengajar 
menggunakan model TSTS terdapat kelemahan pada sistem pembelajaran kooperatif tersebut. Penyampaian informasi yang diberikan oleh anggota kelompok yang bertamu kepada anggota yang tinggal dengan penjelasan lisan dan bahan bacaan membutuhkan waktu pembelajaran yang cukup lama. Selain itu dibutuhkan kemampuan akademik yang tinggi untuk siswa mampu menjelaskan kembali kepada anggota kelompoknya.

Pada penelitian di kelas eksperimen siswa yang dibelajarkan dengan model TSTS diperkaya video, dalam proses pembelajaran dilaksanakan secara berdiskusi ada siswa yang bertamu dan ada siswa yang tinggal. Dalam proses pembelajaran, sebelum siswa berkunjung ke kelompok lain, sebelumnya diadakan terlebih dahulu diskusi internal untuk membahas materi serta video yang telah diberikan guru dalam kelompok masingmasing. Setelah dilaksanakan diskusi internal selanjutnya ada anggota kelompok yang bertamu ke kelompok lain dan ada anggota kelompok yang tinggal.

Pembelajaran dengan model TSTS yang diperkaya video merupakan pembelajaran dengan sistem berkelompok yang bertujuan agar siswa dapat saling belajar dan bekerja sama, saling membantu memecahkan masalah, dan saling mendorong satu sama lain untuk berprestasi, dan bertanggung jawab. Model ini juga melatih siswa untuk bersosialisasi dengan baik.

Wardhani (2012) meneliti mengenai penerapan model pembelajaran kooperatif tipe TSTS disertai media audio-visual untuk meningkatkan kualitas pembelanjaran biologi siswa kelas XI IPA SMA Negeri 7 Surakarta tahun pelajaran 2011/2012. Penerapan model pembelajaran kooperatif tipe TSTS disertai media audio-visual mampu meningkatkan kualitas pembelajaran biologi yang meliputi aspek kinerja guru dalam kelas, fasilitas pembelajaran dalam kelas, iklim kelas, sikap ilmiah siswa dan motivasi belajar siswa. Prasatya dkk. (2017) menambahkan bahwa model pembelajaran TSTS berbasis masalah berpengaruh terhadap hasil belajar IPA.

Untuk mengetahui perbedaan antara siswa yang diberi perlakuan dengan menggunakan model TSTS yang diperkaya video (kelas eksperimen 1) model TSTS (kelas eksperimen 2) dengan kelas yang diberi perlakuan dengan menggunakan model konvensional (kelas kontrol) dilakukan uji Tukey. Dapat disimpulkan bahwa terdapat perbedaan hasil belajar antara kelas yang diberi perlakuan dengan menggunakan model TSTS (kelas eksperimen 2) dengan kelas yang diberi perlakuan menggunakan model konvensional (kelas kontrol). Sedangkan model TSTS yang diperkaya video (kelas eksperimen 1) dengan kelas yang diberi perlakuan dengan menggunakan model TSTS (kelas eksperimen 2).

Berdasarkan hasil wawancara dengan siswa yang telah dibelajarkan menggunakan model TSTS dan TSTS+ video tidak menunjukkan perbedaan hasil belajar yang signifikan. Siswa merasa kesulitan untuk memahami dan menangkap penjelasan dari masing-masing video pembelajaran tersebut. Selain itu siswa juga sudah lelah dengan kegiatan pertukaran informasi dengan berbagai kelompok yang dilakukan secara lisan.

Pelaksanaan pembelajaran dengan model TSTS yang diperkaya video yang dilaksanakan di Madrasah Aliyah Nurul Jalal Kabupaten Tebo tidak menunjukkan perbedaan dengan model TSTS juga disebabkan oleh penggunaan video pembelajaran yang ditayangkan serentak pada setiap kelompok. Volume suara yang berasal dari video-video pada masingmasing kelompok mengganggu konsentrasi siswa dalam memahami materi pembelajaran. 
Berdasarkan hasil uji Anova dua jalur diperoleh, nilai signifikansi $0,937<0,05$. Karena nilai signifikansi lebih besar dari pada 0,05 sehingga dapat disimpulkan bahwa tidak terdapat interaksi model TSTS yang diperkaya video dan motivasi terhadap hasil belajar siswa.

Motivasi merupakan sesuatu yang telah ada dalam diri seseorang, namun setiap orang memiliki motivasi yang berbedabeda, motivasi dapat tumbuh dalam diri seseorang, namun juga dapat menurun. Pada teorinya model kooperatif tipe TSTS dapat memotivasi siswa dalam mencapai tujuan pembelajaran. Namun dalam hasil penelitian yang telah dilakukan model pembelajaran kooperatif tipe TSTS tidak saling berinteraksi dengan motivasi dalam mempengaruhi hasil belajar. Hasil yang diperoleh berbeda dengan para ahli hal ini dikarenakan pada saat penelitian banyak faktor yang mempengaruhinya diantaranya waktu penelitian dilakukan pada jam terakhir pelajaran. Pembelajaran fisika merupakan pembelajaran yang membutuhkan konsentrasi dan melibatkan siswa aktif dalam memahami materi. Pada siang hari suhu ruangan juga cenderung meningkat sehingga mempengaruhi kenyamanan siswa dalam proses pembelajaran yang pada akhirnya mengurangi semangat dan motivasi belajar siswa.

Meskipun tidak terdapat interaksi antara model dan motivasi belajar siswa keduanya diakui oleh beberapa ahli merupakan hal yang sangat penting dalam proses pembelajaran di sekolah. Sama halnya dengan pendapat (Sardiman, 2014) yang menyatakan bahwa kegiatan pembelajaran sangat memerlukan motivasi, karena hasil belajar akan optimal apabila ada motivasi yang diberikan. Selain itu meskipun model pembelajaran tidak terjadi interaksi tetapi para ahli mengakui bahwa model pembelajaran secara langsung mengembangkan interaksi yang saling asuh.

\section{KESIMPULAN}

Penggunaan model pembelajaran TSTS berpengaruh terhadap hasil belajar fisika siswa. Tetapi penggunaan model TSTS yang diperkaya dengan video tidak memberikan pengaruh yang signifikan terhadap hasil belajar dibandingkan dengan penggunaan model TSTS yang biasa. Selain itu juga tidak terlihat adanya interaksi antara model belajar dan motivasi terhadap hasil belajar fisika siswa.

\section{DAFTAR PUSTAKA}

Daud, F. (2012). Pengaruh Kecerdasan Emosional (EQ) dan Motivasi Belajar Terhadap Hasil Belajar Biologi Siswa SMA 3 Negeri Kota Palopo. Jurnal Pendidikan Dan Pembelajaran (JPP), 19(2), 243-255.

Juniari, N. K., Kusmariyatni, N., \& Margunayasa, I. G. (2014). Pengaruh Model Pembelajaran Poe dan Motivasi Belajar Terhadap Hasil Belajar IPA Siswa Kelas V SD. Mimbar PGSD Undiksha, 2(1).

Lie, A. (2002). Cooperative Learning: Implementing Cooperative Learning In The Classroom. Jakarta: PT Gramedia Widiasarana Indonesia.

Muhaji, M., Sahertian, P., \& Priyono, A. (2017). Pengaruh Penerapan Model Pembelajaran Kooperatif Tipe Two Stay-Two Stray (TS-TS) dan Motivasi Belajar Terhadap Hasil Belajar Siswa Mata Pelajaran IPS Siswa SMPN 1 Kecamatan Ngebel Kabupaten Ponorogo. Jurnal Penelitian Dan Pendidikan IPS, 11(1), 76-86.

Prasatya, L. K. L., Murda, I. N., \& Arini, N. W. (2017). Pengaruh Model Pembelajaran TSTS Berbasis Masalah Terhadap Hasil Belajar IPA Siswa Kelas V. Mimbar PGSD 
Undiksha, 5(2).

Rahayu, N. M. N. P., Meter, I. G., \& Suara, I. M. (2014). Pengaruh Pembelajaran Tsts Berbantuan Power Point Terhadap Hasil Belajar Pkn Kelas V Sd Gugus Ii Kecamatan Kuta. Mimbar PGSD Undiksha, 2(1).

Sardiman, A. M. (2014). Interaksi \& Motivasi Belajar Mengajar (cetakan ke 22). Jakarta: PT. Raja Grafindo Persada.

Suprijono, A. (2009). Cooperative Learning Teori \& Aplikasi PAIKEM. Pustaka Pelajar.

Wardhani, I. Y. (2012). Penerapan Model Pembelajaran Kooperatif Tipe Two Stay Two Stray Disertai Media Audio-Visual untuk Meningkatkan Kualitas Pembelajaran Biologi Siswa Kelas XI IPA 5 SMA Negeri 7 Surakarta Tahun Pelajaran 2011/2012. Jurnal Pendidikan Biologi, 4(1), 40-55.

Widiasworo, E. (2015). 19 Kiat Sukses Membangkitkan Motivasi Belajar Peserta Didik. In Jogjakarta: Ar-Ruzz Media. 